\author{
dr Grzegorz TARCZYŃSKI \\ Wydział Zarządzania, Informatyki i Finansów, Uniwersytet Ekonomiczny we Wrocławiu \\ e-mail: grzegorz.tarczynski@ue.wroc.pl
}

\title{
dr Michał JAKUBIAK
}

Wydział Zarządzania, Informatyki i Finansów, Uniwersytet Ekonomiczny we Wrocławiu e-mail: michal.jakubiak@ue.wroc.pl

\section{WPLYW KOMPLETACJI STREFOWEJ, SKŁADOWANIA TOWARÓW I METODY WYZNACZANIA TRASY MAGAZYNIERA NA EFEKTYWNOŚĆ PROCESU KOMPLETACJI ZAMÓWIEŃ}

\begin{abstract}
Streszczenie
W artykule przedstawiono wyniki analizy wpływu różnych czynników na efektywność procesu kompletacji strefowej mierzoną za pomocą średnich czasów kompletacji zamówień i współczynnika wykorzystania stref. W badaniach rozważono dwa rodzaje kompletacji strefowej, tj.: sekwencyjną i synchroniczna. Eksperymenty przeprowadzono z użyciem symulacji i programu Warehouse Real-Time Simulator. Wyniki wskazują, że kompletacja strefowa musi być dobrze zorganizowana. Niewłaściwe dobranie metody składowania towarów do heurystyki wyznaczania trasy przy podziale na strefy może spowodować, że czasy kompletacji będą dłuższe, niż przy magazynie jednostrefowym. Prawidłowe dopasowanie sprawia, że heurystyki dla większości zamówień generują trasy optymalne. Jeżeli towary szybko rotujące są rozłożone równomiernie w strefach, to problem nierównowagi nakładu pracy w strefach dla kompletacji sekwencyjnej prawie nie występuje, a dla kompletacji synchronicznej nie przekracza $20 \%$.
\end{abstract}

Słowa kluczowe: kompletacja strefowa, składowanie towarów, wyznaczanie trasy, symulacje

\section{IMPACT OF ZONE PICKING, STORING AND ROUTING ON AVERAGE ORDER- PICKING TIME}

\begin{abstract}
Summary
The paper presents the results of an analysis of the influence of different factors on zone picking efficiency, as measured by the average order-picking times and the average utilization of zone pickers. The study considers two versions of zone picking: sequential and synchronized. The research was performed using simulations and the Warehouse-Real Time Simulator. The results indicate that zone picking has to be well organized. Improper choice of storage policy to routing method while zone picking may lengthen order-picking times as compared to those without zone division. However, proper selection can ensure optimal routes. When fast moving items are similarly distributed in all zones, the problem of imbalance of zone utilization for sequential picking hardly exists, and for synchronized picking does not exceed $20 \%$.
\end{abstract}

Key words: zone picking, storage assignment, picker routing, simulations

JEL: C53 


\section{Wstęp}

Podstawową miarą oceny efektywności magazynowej jest średni czas kompletacji zamówień. Istnieje pięć podstawowych grup czynników, które wpływają na czasy kompletacji, tj.: układ magazynu (layout), czyli liczba i długość alejek, liczba poprzecznych korytarzy, umiejscowienie punktu I/O, w którym magazynier zaczyna i zazwyczaj kończy kompletacje zlecenia; sposób składowania towarów (storage location assignment), sposób wyznaczania trasy magazyniera (order routing); podział magazynu na strefy (zoning) oraz tworzenie zleceń łączonych (order batching) [Yu, de Koster, 2009, s. 480-490]. De Koster $\mathrm{i}$ inni [2007, s. 481-501] przedstawili krótki opis metod pozwalających na rozwiązanie wymienionych problemów i szczegółowy przegląd literatury.

Artykuł jest poświęcony sposobom kompletacji zamówień przy podziale magazynu na strefy kompletacyjne. Frazelle i Apple [1994, s. 22.1-22.36] wyróżnili trzy takie metody, a mianowicie: sekwencyjna (sequentia), strefowa zleceń łączonych (batch zone) i falowa (wave picking). Kompletacja sekwencyjna (w literaturze funkcjonują również inne nazwy, takie jak: pick-and-pass i progressive) polega na kompletacji pojedynczych zamówień $\mathrm{w}$ rozbiciu na strefy. Towary sa zbierane najpierw w jednej strefie, a następnie pojemnik z pobranymi już artykułami trafia do dalszych stref, gdzie uzupełnia się go kolejnymi wyrobami. Takie rozwiązanie nie wymaga konieczności sortowania wyrobów. Po przejściu wszystkich niezbędnych stref magazynowych, w pojemniku znajduje się zestaw towarów z jednego zamówienia. Z kolei, strefowa kompletacja zleceń łączonych w literaturze jest raczej określana jako kompletacja synchroniczna (synchronized, ale równocześnie funkcjonują nazwy paralleli simultaneous). Polega ona na tworzeniu zleceń kompletacyjnych złożonych z więcej niż jednego zamówienia. Zlecenie jest pobierane do osobnych pojemników w każdej ze stref w tym samym czasie. Rozpoczęcie kompletacji nowego zlecenia wymaga zakończenia kompletacji poprzedniego we wszystkich strefach. Taka organizacja pracy powoduje, że wyroby po pobraniu będą musiały być posortowane. Również pojawia się tutaj niebezpieczeństwo nierównowagi nakładu pracy w strefach. Ostatnia z wymienionych metod, kompletacja falowa, stanowi odmianę kompletacji synchronicznej, w której zlecenia kompletacyjne powstaja poprzez połączenie bardzo dużej liczby zamówień. Petersen [2000, s. 319-335] stwierdził, że długość fal wynosi zazwyczaj od 30 minut do 2 godzin. W artykule Petersena można także znaleźć informacje na temat podstawowych zalet i wad zaprezentowanych koncepcji.

Przedstawiony opis nie jest precyzyjny. Yu i de Koster [2009, s. 480-490] rozważyli na przykład kompletację sekwencyjną zleceń łączonych. Takie rozwiązanie wymusza zainstalowanie w magazynie sortowni, nierzadko automatycznej.

Badaniem efektywności kompletacji sekwencyjnej zajmowali się m.in.: de Koster [1994, s. 558-573], Petersen [2000, s. 319-335], Yu i de Koster [2008, s. 1054-1069; 2009, s. 480-490], Melacini i inni [2010, s. 841-854], Gaast i inni [2012, s. 1-27]. Kompletacji strefowej synchronicznej poświęcono artykuły: Petersena [2000, s. 319-335], Jane’a i Laiha [2005, s. 489-496] oraz Le Duca i de Kostera [2005, s. 1-28]. Według wiedzy autorów, w literaturze brakuje badań łączących wybór metody kompletacji strefowej ze sposobem składowania towarów, a zarazem problemem doboru heurystyki wyznaczającej trasę magazyniera. Temu właśnie zagadnieniu jest poświęcony ten artykuł. 


\section{Parametry procesu kompletacji zamówień wykorzystane w badaniach}

W badaniach empirycznych sprawdzono wzajemny wpływ: wyboru sposobu podziału na strefy i metody kompletacji strefowej, polityki składowania towarów szybko rotujących oraz heurystyki wyznaczania trasy magazyniera na efektywność procesu kompletacji zamówień mierzoną za pomoca średnich czasów kompletacji oraz współczynników wykorzystania stref wyrażających nierównowagę nakładu pracy w strefach. Przyjęto następujące parametry:

- $\quad$ układ magazynu (rysunek 1.): jednoblokowy, prostokątny z 30 alejkami (zbadano trzy warianty, tj.: bez podziału na strefy, z 3 strefami po 10 alejek, z 5 strefami po 6 alejek);

- punkt I/O, z którego magazynierzy pobieraja pojemniki i ewentualnie (wobec braku urządzeń elektronicznych) zlecenia kompletacyjne, znajduje się w rogu magazynu. Wzdłuż dolnego korytarza jest ulokowany przenośnik taśmowy (rolkowy), na który są odkładane pojemniki po skompletowaniu towarów w strefie. W przypadku kompletacji synchronicznej pojemniki są transportowane do sortowni, gdzie zamówienia są sortowane i scalane. W przypadku kompletacji sekwencyjnej pojemniki oznaczone kodami kreskowymi są transportowane do kolejnych stref, gdzie są skanowane $\mathrm{i}-\mathrm{w}$ razie potrzeby - w automatyczny sposób odstawiane na specjalnie wydzielony dla każdej strefy fragment przenośnika (tworzący bufor), skąd pojemniki są pobierane celem uzupełnienia towarów. Przyjmuje się nieograniczona pojemność bufora (de Koster zauważył, że jeżeli istnieje ryzyko przepełnienia bufora, można poinstruować pracowników, aby tymczasowo zdjęli pojemniki z przenośnika i umieścili je na podłodze [de Koster, 1994, s. 558-573]);

- $\quad$ rozkłady towarów szybko rotujących w każdej ze stref są takie same;

- $\quad$ każde zamówienie składa się z 10 różnych towarów (w przypadku kompletacji strefowej synchronicznej zlecenia w poszczególnych strefach są scalane tak, aby magazynier podczas jednego cyklu odwiedzał co najwyżej 10 lokalizacji); liczba pobieranych wyrobów tego samego typu jest pomijana w analizie;

- $\quad$ sposoby rozmieszczenia towarów szybko rotujących w magazynie: całkowicie losowo oraz na podstawie klasyfikacji ABC (class-based storage assignment), polityka within aisle (towary z klasy A umieszcza się w sposób losowy w alejkach najbliższych punktowi I/O), polityka across aisle (towary z klasy A umieszcza się losowo we wszystkich alejkach na lokalizacjach najbliższych korytarzowi, przy którym jest umieszczony przenośnik);

- metody wyznaczania trasy magazyniera: trasa optymalna (wytyczona zgodnie $\mathrm{z}$ algorytmem Ratliffa i Rosenthala [1983, s. 507-521]) i heurystyki: s-shape, midpoint, return, largest gap, combined (szczegółowy opis metod można znaleźć np. w pracy Tarczyńskiego [2012, s. 105-120]);

- dla magazynu bez podziału na klasy oraz przy kompletacji strefowej synchronicznej stosuje się kompletację bezpośrednią zamówień 1:1 i 1:n; przy kompletacji strefowej sekwencyjnej tworzy się zlecenia poprzez połączenie zamówień w rozbiciu na strefy (kompletacja m:n); 
- $\quad$ parametry techniczne magazynu: szerokość regału 2,65 m, szerokość alejek $3 \mathrm{~m}$, szerokość głównych korytarzy 3,4 m, średnia prędkość poruszania się magazyniera $5 \mathrm{~m} / \mathrm{s}$, czas pobrania towaru $10 \mathrm{~s}$.

RYSUNEK 1. Magazyn z trzema strefami połączonymi przenośnikiem taśmowym z sortownią
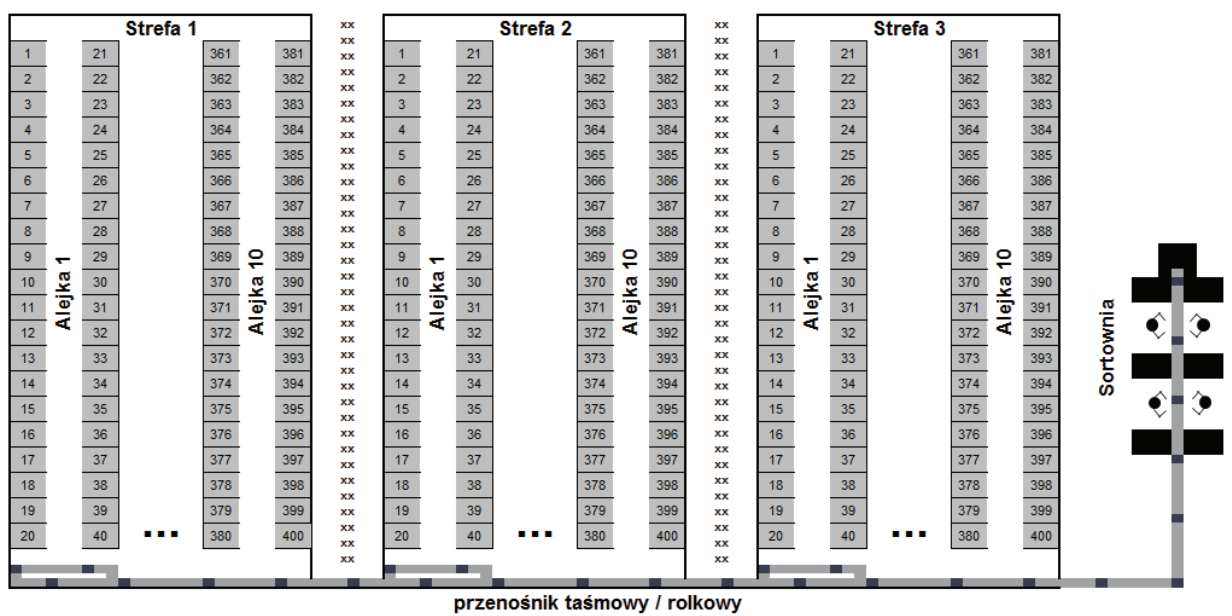

Źródło: opracowanie własne.

Metodą badawczą wykorzystaną do badań są symulacje komputerowe. Obliczenia zostały wykonane z wykorzystaniem programu Warehouse Real-Time Simulator [Tarczyński, 2013, s. 1-18]. Dla każdego badanego wariantu decyzyjnego wykonano 20 tys. replikacji (jedna replikacja oznacza jedno zamówienie, które należy skompletować).

\section{Badanie efektywności kompletacji strefowej - wyniki obliczeń}

Zostały wyznaczone średnie czasy kompletacji dla 90 wariantów decyzyjnych z wykorzystaniem narzędzi symulacyjnych (tabela 1.). Wszystkie warianty porównano z wariantem, w którym kompletacja odbywała się bez podziału na strefy, towary składowano w sposób całkowicie losowy, a trasę magazynierów ustalono z wykorzystaniem heurystyki s-shape, którą zdecydowanie najczęściej stosuje się w praktyce. Dzięki właściwemu składowaniu towarów jest możliwe poprawienie wyników o 26,93\%, bez konieczności zmiany metody wyznaczania trasy. Gdyby magazynierzy poruszali się po najkrótszej trasie, to redukcja średnich czasów kompletacji wyniosłaby 41,03\%. Zastosowanie kompletacji strefowej sekwencyjnej, zarówno dla magazynu trzystrefowego, jak i pięciostrefowego, powoduje dalszą redukcję, ale już nie tak wyraźna, o kilka punktów procentowych. Najlepsze wyniki - skrócenie czasu o blisko 70\% w stosunku do wariantu wzorcowego uzyskano dla kompletacji synchronicznej. Wariantem najkorzystniejszym jest ten, w którym wyróżniono 5 stref, towary składowano zgodnie z polityką within-aisle, a magazynierzy 
poruszali się po najkrótszej trasie - poprawa wyniku o $69,12 \%$. Tylko niewiele gorsze rezultaty uzyskano dla metod wyznaczania trasy, które są łatwe do zastosowania w praktyce, a mianowicie: heurystyki s-shape z polityka within aisle $(65,03 \%)$ oraz heurystyki return z polityką across-aisle (64,58\%). Jednak należy pamiętać, że strefowa kompletacja zleceń łączonych wymaga dodatkowego nakładu pracy w sortowni lub dużych nakładów finansowych na zainstalowanie sortowni automatycznej.

Heurystyki: midpoint, return, largest gap i combined najefektywniej funkcjonowaly przy składowaniu zgodnym z polityką across-aisle. Z kolei, metoda s-shape była najskuteczniejsza w sytuacji, gdy wdrożono politykę składowania towarów within-aisle. Warta uwagi jest pewna prawidłowość, która cechowała heurystykę s-shape w magazynach podzielonych na strefy. W tych przypadkach składowanie towarów na podstawie klasyfikacji ABC przyniosła bardzo niewielką poprawę wyników w porównaniu ze składowaniem losowym.

Rysunek 2. obrazuje zmiany liczby wygenerowanych zleceń (list kompletacyjnych) dla poszczególnych wariantów. Dla kompletacji strefowej sekwencyjnej liczba wygenerowanych zleceń wyniosła około $295 \%$ wariantu podstawowego przy magazynach trzystrefowych i blisko $450 \%$ dla magazynów pięciostrefowych. Kompletacja synchroniczna powodowała, że zamówienia w ramach stref były łączone, czego następstwem było to, że liczba zleceń dla 3 stref stanowiła około $102,6 \%$, a dla 5 stref około $100,2 \%$ liczby pierwotnych zamówień.

RYSUNEK 2.

\section{Liczba zleceń realizowanych przy różnych wariantach organizacji stref kompletacji}

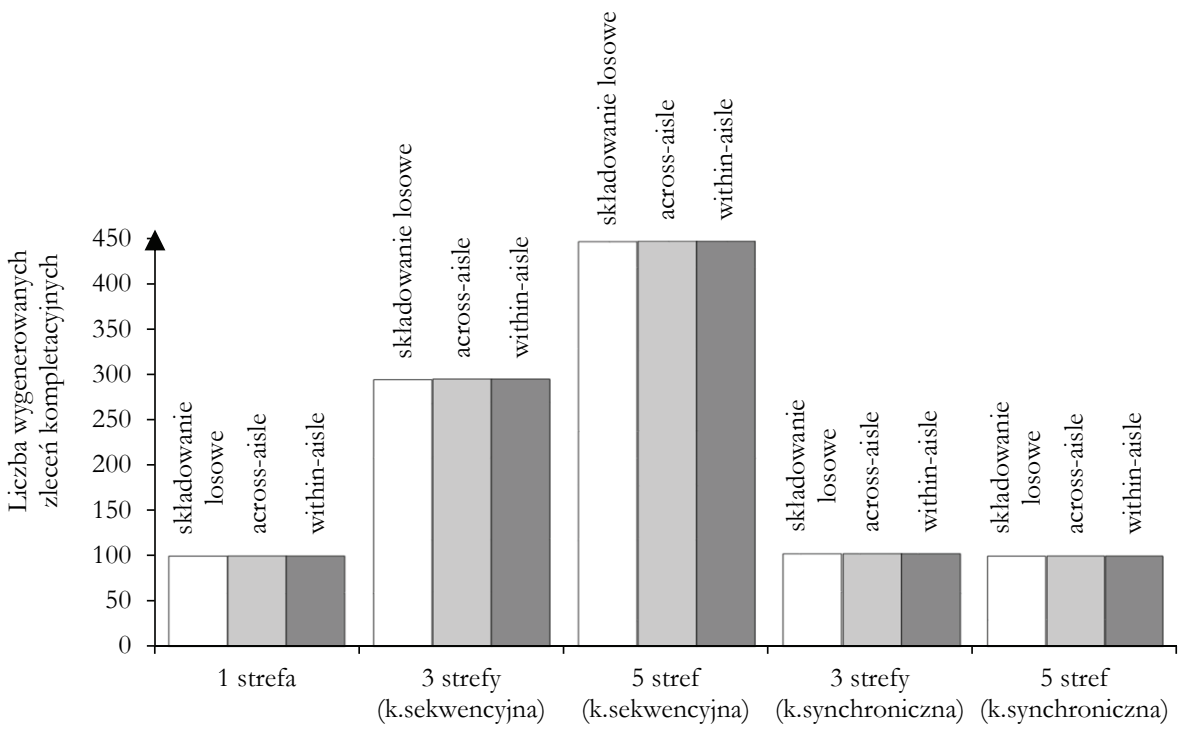

Źródło: opracowanie własne. 
TABELA 1.

Średnie czasy kompletacji dla różnych wariantów (w nawiasach podano procentową poprawę czasu względem wariantu jednostrefowego z losowym rozmieszczeniem towarów i heurystyką s-shape)

\begin{tabular}{|c|c|c|c|c|c|c|c|}
\hline \multirow[t]{2}{*}{ Podział na strefy } & \multirow[t]{2}{*}{ Składowanie } & \multicolumn{6}{|c|}{ Metoda wyznaczania trasy } \\
\hline & & s-shape & midpoint & return & largest gap & combined & optimal \\
\hline \multirow{3}{*}{1 strefa } & losowe & $\begin{array}{c}27: 14 \\
(0,00 \%)\end{array}$ & $\begin{array}{c}22: 13 \\
(18,44 \%) \\
\end{array}$ & $\begin{array}{c}28: 56 \\
(-6,27 \%) \\
\end{array}$ & $\begin{array}{c}22: 01 \\
(19,17 \%) \\
\end{array}$ & $\begin{array}{c}24: 15 \\
(10,92 \%) \\
\end{array}$ & $\begin{array}{c}21: 05 \\
(22,60 \%)\end{array}$ \\
\hline & across-aisle & $\begin{array}{c}26: 30 \\
(2,70 \%)\end{array}$ & $\begin{array}{c}17: 06 \\
(37,23 \%)\end{array}$ & $\begin{array}{c}17: 07 \\
(37,14 \%)\end{array}$ & $\begin{array}{c}17: 04 \\
(37,34 \%)\end{array}$ & $\begin{array}{c}17: 09 \\
(37,02 \%)\end{array}$ & $\begin{array}{c}16: 38 \\
(38,90 \%)\end{array}$ \\
\hline & within-aisle & $\begin{array}{c}19: 54 \\
(26,93 \%)\end{array}$ & $\begin{array}{c}18: 08 \\
(33,44 \%)\end{array}$ & $\begin{array}{c}22: 34 \\
(17,16 \%) \\
\end{array}$ & $\begin{array}{c}17: 37 \\
(35,31 \%)\end{array}$ & $\begin{array}{c}18: 17 \\
(32,87 \%)\end{array}$ & $\begin{array}{c}16: 04 \\
(41,03 \%)\end{array}$ \\
\hline \multirow{3}{*}{$\begin{array}{c}3 \text { strefy } \\
\text { kompletacja sekwencyjna }\end{array}$} & losowe & $\begin{array}{c}18: 54 \\
(30,61 \%) \\
\end{array}$ & $\begin{array}{c}18: 46 \\
(31,06 \%)\end{array}$ & $\begin{array}{c}21: 08 \\
(22,41 \%) \\
\end{array}$ & $\begin{array}{c}18: 23 \\
(32,50 \%) \\
\end{array}$ & $\begin{array}{c}17: 59 \\
(33,98 \%) \\
\end{array}$ & $\begin{array}{c}16: 51 \\
(38,13 \%) \\
\end{array}$ \\
\hline & across-aisle & $\begin{array}{c}24: 07 \\
(11,44 \%) \\
\end{array}$ & $\begin{array}{c}15: 52 \\
(41,71 \%) \\
\end{array}$ & $\begin{array}{c}15: 49 \\
(41,89 \%) \\
\end{array}$ & $\begin{array}{c}15: 51 \\
(41,81 \%) \\
\end{array}$ & $\begin{array}{c}15: 50 \\
(41,83 \%) \\
\end{array}$ & $\begin{array}{c}15: 35 \\
(42,76 \%) \\
\end{array}$ \\
\hline & within-aisle & $\begin{array}{c}18: 43 \\
(31,27 \%)\end{array}$ & $\begin{array}{c}18: 39 \\
(31,52 \%)\end{array}$ & $\begin{array}{c}20: 52 \\
(23,37 \%)\end{array}$ & $\begin{array}{c}18: 15 \\
(32,96 \%)\end{array}$ & $\begin{array}{c}17: 49 \\
(34,56 \%)\end{array}$ & $\begin{array}{c}16: 45 \\
(38,48 \%)\end{array}$ \\
\hline \multirow{3}{*}{$\begin{array}{c}5 \text { stref } \\
\text { kompletacja sekwencyjna }\end{array}$} & losowe & $\begin{array}{c}19: 53 \\
(26,97 \%)\end{array}$ & $\begin{array}{c}20: 07 \\
(26,13 \%)\end{array}$ & $\begin{array}{c}22: 00 \\
(19,18 \%)\end{array}$ & $\begin{array}{c}19: 54 \\
(26,90 \%)\end{array}$ & $\begin{array}{c}19: 28 \\
(28,54 \%)\end{array}$ & $\begin{array}{c}18: 59 \\
(30,31 \%)\end{array}$ \\
\hline & across-aisle & $\begin{array}{c}21: 57 \\
(19,42 \%) \\
\end{array}$ & $\begin{array}{c}14: 53 \\
(45,36 \%) \\
\end{array}$ & $\begin{array}{c}14: 50 \\
(45,55 \%) \\
\end{array}$ & $\begin{array}{c}14: 52 \\
(45,43 \%) \\
\end{array}$ & $\begin{array}{c}14: 51 \\
(45,49 \%) \\
\end{array}$ & $\begin{array}{c}14: 41 \\
(46,07 \%) \\
\end{array}$ \\
\hline & within-aisle & $\begin{array}{c}19: 51 \\
(27,11 \%) \\
\end{array}$ & $\begin{array}{c}20: 08 \\
(26,05 \%) \\
\end{array}$ & $\begin{array}{c}22: 01 \\
(19,16 \%) \\
\end{array}$ & $\begin{array}{c}19: 55 \\
(26,84 \%) \\
\end{array}$ & $\begin{array}{c}19: 28 \\
(28,51 \%) \\
\end{array}$ & $\begin{array}{c}18: 59 \\
(30,29 \%) \\
\end{array}$ \\
\hline \multirow{3}{*}{$\begin{array}{l}3 \text { strefy } \\
\text { kompletacja synchroniczna }\end{array}$} & losowe & $\begin{array}{c}11: 48 \\
(56,68 \%) \\
\end{array}$ & $\begin{array}{c}12: 48 \\
(52,97 \%) \\
\end{array}$ & $\begin{array}{c}14: 31 \\
(46,69 \%) \\
\end{array}$ & $\begin{array}{c}12: 12 \\
(55,21 \%) \\
\end{array}$ & $\begin{array}{c}11: 23 \\
(58,21 \%) \\
\end{array}$ & $\begin{array}{c}10: 11 \\
(62,63 \%) \\
\end{array}$ \\
\hline & across-aisle & $\begin{array}{c}18: 03 \\
(33,72 \%)\end{array}$ & $\begin{array}{c}11: 42 \\
(57,06 \%)\end{array}$ & $\begin{array}{c}11: 37 \\
(57,31 \%)\end{array}$ & $\begin{array}{c}11: 37 \\
(57,32 \%)\end{array}$ & $\begin{array}{c}11: 37 \\
(57,36 \%)\end{array}$ & $\begin{array}{c}11: 10 \\
(58,98 \%)\end{array}$ \\
\hline & within-aisle & $\begin{array}{c}11: 38 \\
(57,26 \%) \\
\end{array}$ & $\begin{array}{c}12: 42 \\
(53,35 \%) \\
\end{array}$ & $\begin{array}{c}14: 17 \\
(47,57 \%) \\
\end{array}$ & $\begin{array}{c}12: 06 \\
(55,59 \%) \\
\end{array}$ & $\begin{array}{c}11: 15 \\
(58,72 \%) \\
\end{array}$ & $\begin{array}{c}10: 06 \\
(62,90 \%)\end{array}$ \\
\hline \multirow{3}{*}{$\begin{array}{c}5 \text { stref } \\
\text { kompletacja synchroniczna }\end{array}$} & losowe & $\begin{array}{c}9: 34 \\
(64,86 \%) \\
\end{array}$ & $\begin{array}{c}10: 35 \\
(61,12 \%) \\
\end{array}$ & $\begin{array}{c}12: 19 \\
(54,76 \%) \\
\end{array}$ & $\begin{array}{c}10: 12 \\
(62,52 \%) \\
\end{array}$ & $\begin{array}{c}9: 04 \\
(66,74 \%) \\
\end{array}$ & $\begin{array}{c}8: 26 \\
(69,02 \%) \\
\end{array}$ \\
\hline & across-aisle & $\begin{array}{c}13: 53 \\
(49,01 \%)\end{array}$ & $\begin{array}{c}9: 47 \\
(64,06 \%)\end{array}$ & $\begin{array}{c}9: 39 \\
(64,58 \%) \\
\end{array}$ & $\begin{array}{c}9: 41 \\
(64,43 \%)\end{array}$ & $\begin{array}{c}9: 36 \\
(64,72 \%) \\
\end{array}$ & $\begin{array}{c}9: 14 \\
(66,12 \%)\end{array}$ \\
\hline & within-aisle & $\begin{array}{c}9: 31 \\
(65,03 \%) \\
\end{array}$ & $\begin{array}{c}10: 32 \\
(61,30 \%)\end{array}$ & $\begin{array}{c}12: 18 \\
(54,85 \%)\end{array}$ & $\begin{array}{c}10: 11 \\
(62,61 \%)\end{array}$ & $\begin{array}{c}8: 59 \\
(67,02 \%) \\
\end{array}$ & $\begin{array}{c}8: 24 \\
(69,12 \%) \\
\end{array}$ \\
\hline
\end{tabular}

Źródło: opracowanie własne.

Na rysunku 3. przedstawiono wykresy dystrybuanty czasów kompletacji zamówień dla często stosowanej w praktyce heurystyki s-shape w magazynie jednostrefowym i sekwencyjnym trzystrefowym. Dla drugiego wariantu średni czas kompletacji był krótszy o 5,9\%. Różnica z pozoru niewielka, ale w przypadku magazynu trzystrefowego największa liczba zamówień (12,47\%) była kompletowana w czasie od 16 do 17 minut, a dla magazynu jednostrefowego było to $12,11 \%$ i przedział o dwie minuty dłuższy. Dla magazynu jednostrefowego połowa zamówień została skompletowana w czasie 19:48, a w przypadku trzech stref w 18:37. Co ciekawe, dla zamówień, dla których czasy kompletacji były najkrótsze, lepsze wyniki uzyskano przy kompletacji jednostrefowej. Dla 3\% najszybciej kompletowanych zamówień średni czas kompletacji był lepszy o około 2\%, jeśli nie dokonano podziału na strefy. Dzieje się tak, gdy wszystkie pobierane towary znajduja się w dwóch pierwszych alejkach. W przypadku podziału na strefy rośnie szansa na to, że wyroby trzeba będzie pobierać z kilku stref, co zwiększy czas obsługi zlecenia. Jeśli 
porówna się czasy kompletacji pojedynczych zamówień (rysunek 4.), to można zaobserwować, że dla 65,32\% zamówień czasy kompletacji w magazynie trzystrefowym były krótsze niż przy braku podziału na strefy, dla 0,43\% takie same, a dla pozostałych $34,25 \%$ dłuższe. Dla zamówień, dla których wariant jednostrefowy był lepszy, różnica czasów była stosunkowo niewielka. Przykładowo tylko dla 1,77\% zamówień czas kompletacji w magazynie jednostrefowym był krótszy o co najmniej 5 minut niż w przypadku, gdy były one kompletowane w trzech strefach, natomiast aż dla 10,56\% zamówień różnica czasów wynosiła co najmniej 5 minut na korzyść magazynu trzystrefowego.

RYSUNEK 3.

Dystrybuanta czasów kompletacji zamówień dla heurystyki s-shape i najlepszych wariantów w magazynie jednostrefowym (składowanie within aisle) i sekwencyjnym trzystrefowym (składowanie within aisle)

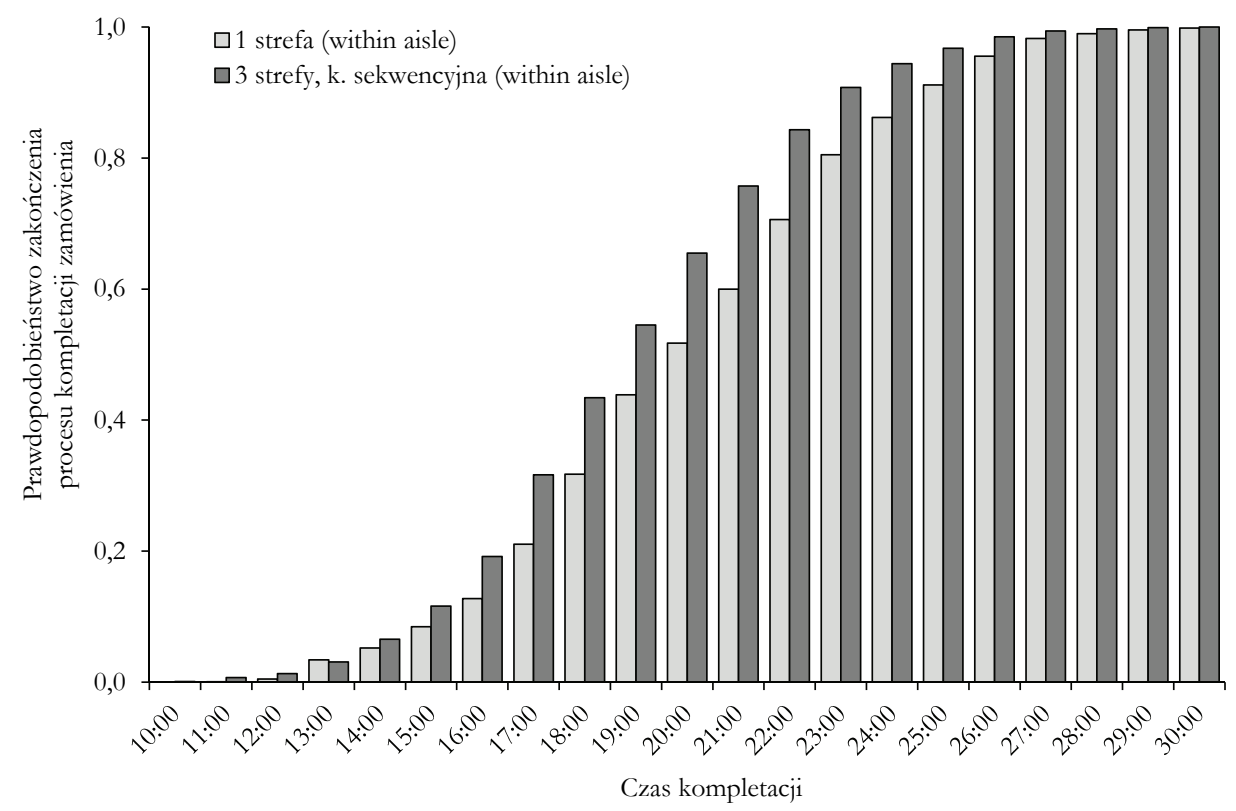

Źródło: opracowanie własne.

Drugą heurystyką, łatwą do wdrożenia, jest heurystyka return. Kompletacja, zgodnie z tą metoda, daje bardzo dobre wyniki, ale tylko w połączeniu z polityką składowania across-aisle. Na rysunku 5. przedstawiono porównanie czasów kompletacji poszczególnych zamówień dla heurystyki return w magazynie jednostrefowym i sekwencyjnym pięciostrefowym. Dla około 76,60\% zamówień wariant trzystrefowy okazał się lepszy, a dla $23,06 \%$ gorszy ( $0,34 \%$ zamówień zostało skompletowanych w takim samym czasie). Tylko 2,05\% zamówień było kompletowanych w jednej strefie szybciej o co najmniej 5 minut niż przy trzech strefach. Z kolei, dla aż 19,92\% zamówień czasy w magazynie trzystrefowym były krótsze o co najmniej 5 minut. 


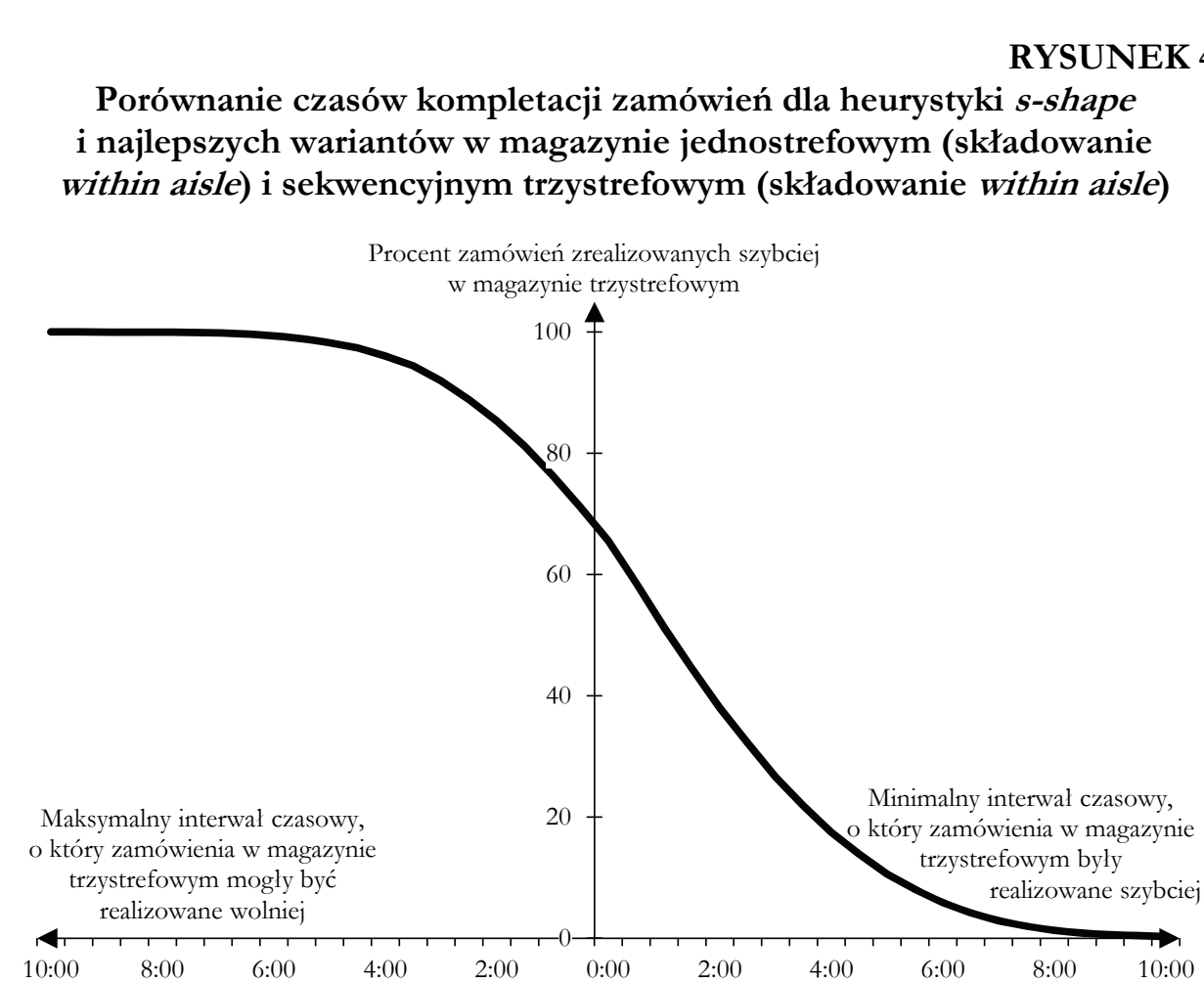

Źródło: opracowanie własne.

Rozkłady prawdopodobieństwa czasów kompletacji zamówień w magazynie pięciostrefowym dla kompletacji synchronicznej i różnych polityk składowania towarów przedstawiono na rysunkach: 6. i 7. Wyznaczając trasę zgodnie z heurystyką s-shape i przy składowaniu within-aisle, najwięcej zamówień, gdyż 32,59\%, zostało pobranych w bardzo krótkim czasie od 6 do 8 minut, a aż 97,86\% w czasie 6-14 minut. Stosując politykę acrossaisle, czas kompletacji dla aż 54,96\% zamówień wynosił od 12 do 14 minut, a dla 27,65\% 16-18 minut. Zupełnie inne wyniki uzyskano dla heurystyki s-shape. Czas pobrania, aż $87,70 \%$, zamówień wyniósł od 6 do 12 minut, z czego 42,01\% od 8 do 10 minut, ale przy składowaniu across-aisle. Dla polityki within-aisle wyniki były dużo gorsze: $56,67 \%$ zamówień kompletowano w czasie 10-14 minut, a 24,35\% jeszcze dłużej. Krótkich czasów kompletacji zamówień nie da się więc osiagnąc ani przez samo składowanie towarów szybko rotujących, ani przez dobór trasy magazyniera. Tylko połączenie tych dwóch elementów gwarantuje poprawę wyników. Z wykresów jeszcze wynika, że dla heurystyk: midpoint, return, largerst gap i combined rozkłady prawdopodobieństwa zakończenia procesu kompletacji w określonym czasie były do siebie bardzo zbliżone, a także bliskie czasom optymalnym. 
RYSUNEK 5.

Porównanie czasów kompletacji zamówień dla heurystyki return i najlepszych wariantów w magazynie jednostrefowym (składowanie across aisle) i sekwencyjnym pięciostrefowym (składowanie across aisle)

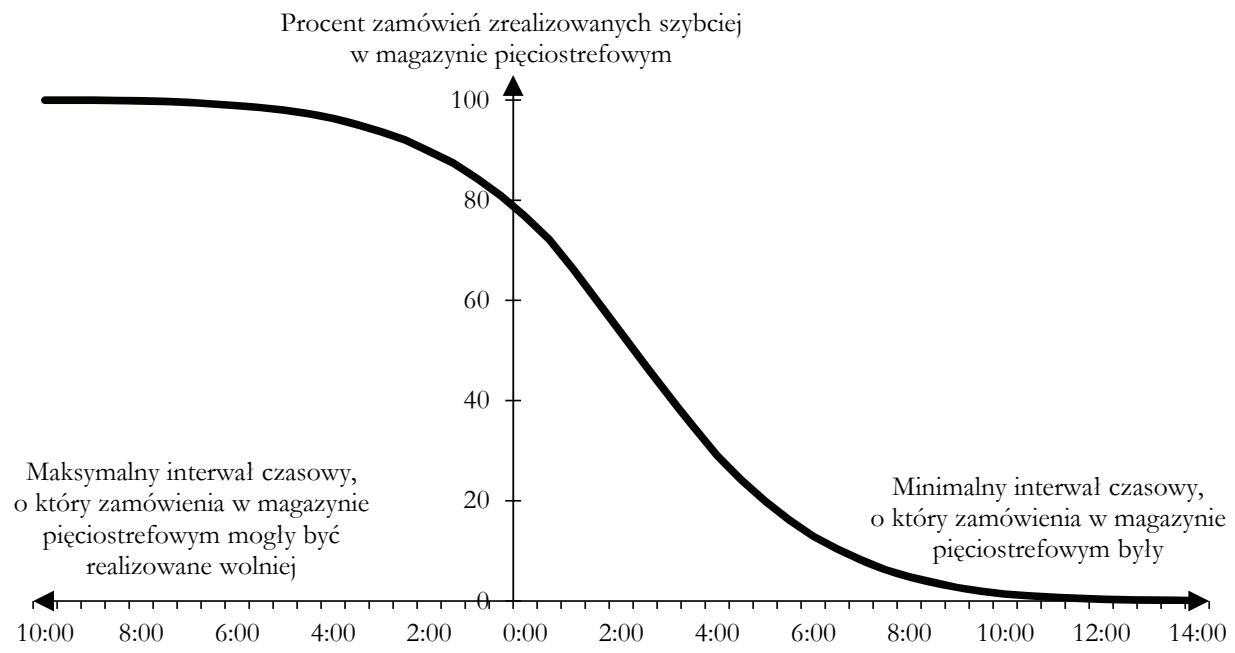

Źródło: opracowanie własne.

RYSUNEK 6.

Rozkłady prawdopodobieństwa czasu kompletacji w przeliczeniu na pojedyncze zamówienie dla kompletacji synchronicznej pięciostrefowej, składowania across-aisle i różnych sposobów wyznaczania trasy

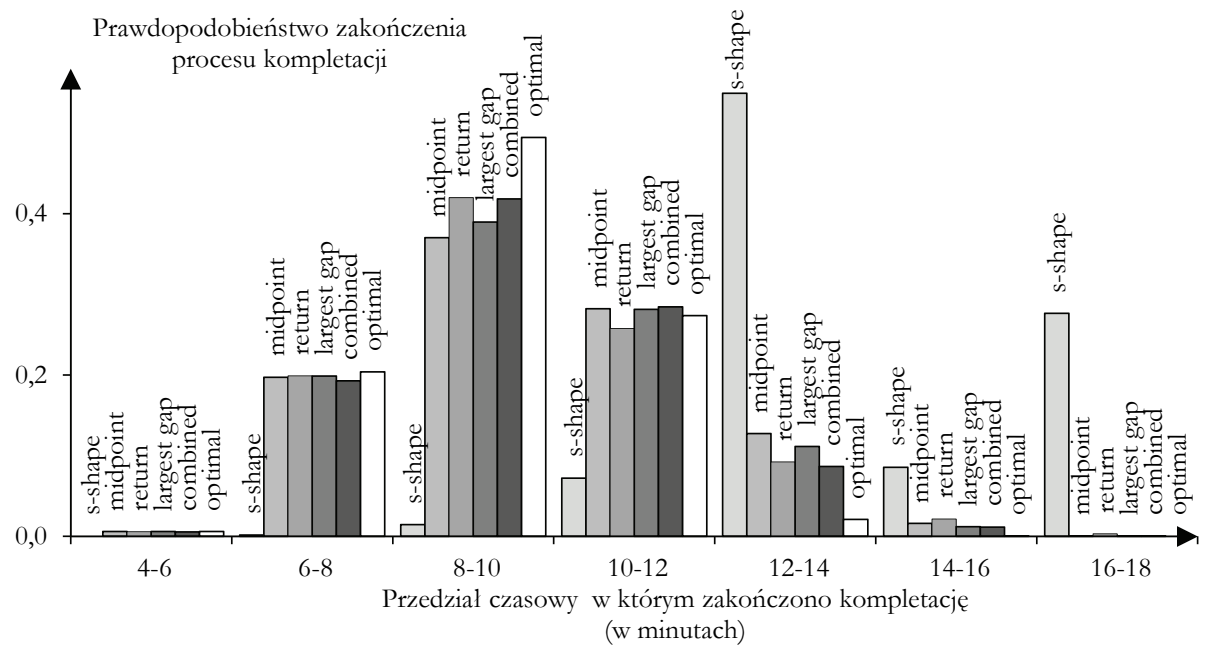

Źródło: opracowanie własne. 


\section{RYSUNEK 7. \\ Rozkłady prawdopodobieństwa czasu kompletacji w przeliczeniu na pojedyncze zamówienie dla kompletacji synchronicznej pięciostrefowej, składowania within-aisle i różnych sposobów wyznaczania trasy}

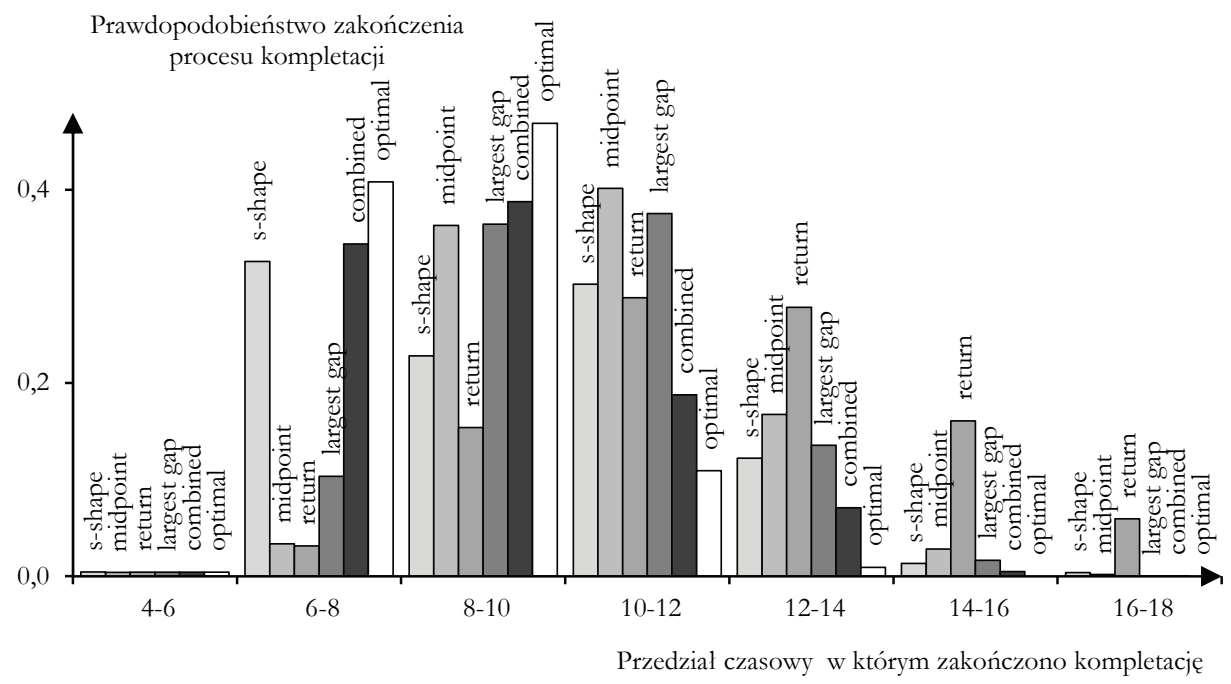

Źródło: opracowanie własne.

Na rysunkach: 8. i 9. pokazano, dla jakiego procentu zamówień trasa wygenerowana za pomoca poszczególnych heurystyk w magazynach trzystrefowych była optymalna. Dla heurystyk: midpoint, return, largest gap $\mathrm{i}$ combined $\mathrm{w}$ połączeniu ze składowaniem acrossaisle dla blisko $60 \%$ zleceń przy kompletacji sekwencyjnej i około $50 \%$ przy kompletacji synchronicznej wygenerowane trasy przejścia były najkrótsze z możliwych. Oznacza to, że nie ma potrzeby wdrażania w magazynie systemu, który kieruje magazynierów na drogę optymalną. Zbliżone efekty można uzyskać za pomoca prostych heurystyk w połączeniu z właściwym składowaniem towarów szybko rotujących.

Niezwykle istotne jest właściwe ułożenie w magazynie towarów szybko rotujących. Przy kompletacji sekwencyjnej i podziale na trzy strefy zastosowanie polityki across-aisle powodowały, że czasy kompletacji dla większości heurystyk, takich jak: midpoint, return, largest gap i combined, były bliskie optymalnym, a mianowicie średnie wartości były gorsze od optymalnych o 1,52\% do 1,83\%. Dla metody s-shape ułożenie towarów szybko rotujących wzdłuż głównego korytarza przyniosło pogorszenie wyników w stosunku do rozmieszczenia losowego. Tutaj najlepsze wyniki uzyskała polityka within-aisle, a czas kompletacji był dłuższy od optymalnego dla tej polityki o 11,71\% i tylko o trochę lepszy niż przy rozmieszczeniu losowym towarów. Przy podziale na pięć stref $i$ wdrożeniu polityki across-aisle dla kompletacji sekwencyjnej średnie czasy kompletacji dla heurystyk (za wyjątkiem $s$-shape) także były bliskie wartościom optymalnym (były gorsze od $0,98 \%$ do $1,32 \%$ ). S-shape w połączeniu z rozmieszczeniem within-aisle przy pięciu strefach dało 
już czasy kompletacji niemal optymalne, a średnio dłuższe o 4,55\%. Również dla kompletacji strefowej synchronicznej heurystyki: midpoint, return, largest gap i combined przyniosły najlepsze rezultaty (i bliskie wartościom optymalnym) w połączeniu z polityka across-aisle (czasy kompletacji przekroczyły najkrótsze możliwe wartości o 3,93\%-4,66\% dla 3 stref i 4,13\%-6,07\% dla 5 stref). Dla heurystyki s-shape duża liczba towarów na zleceniu, którą implikują wymagania kompletacji strefowej synchronicznej, spowodowała, że wdrożenie składowania zgodnego z polityką witbin-ailse w bardzo niewielkim stopniu skróciło czas kompletacji.

RYSUNEK 8.

Odsetek zleceń, dla których trasa kompletacji odpowiadała trasie optymalnej przy kompletacji sekwencyjnej trzystrefowej, dla różnych heurystyk wyznaczania trasy i metod składowania towarów

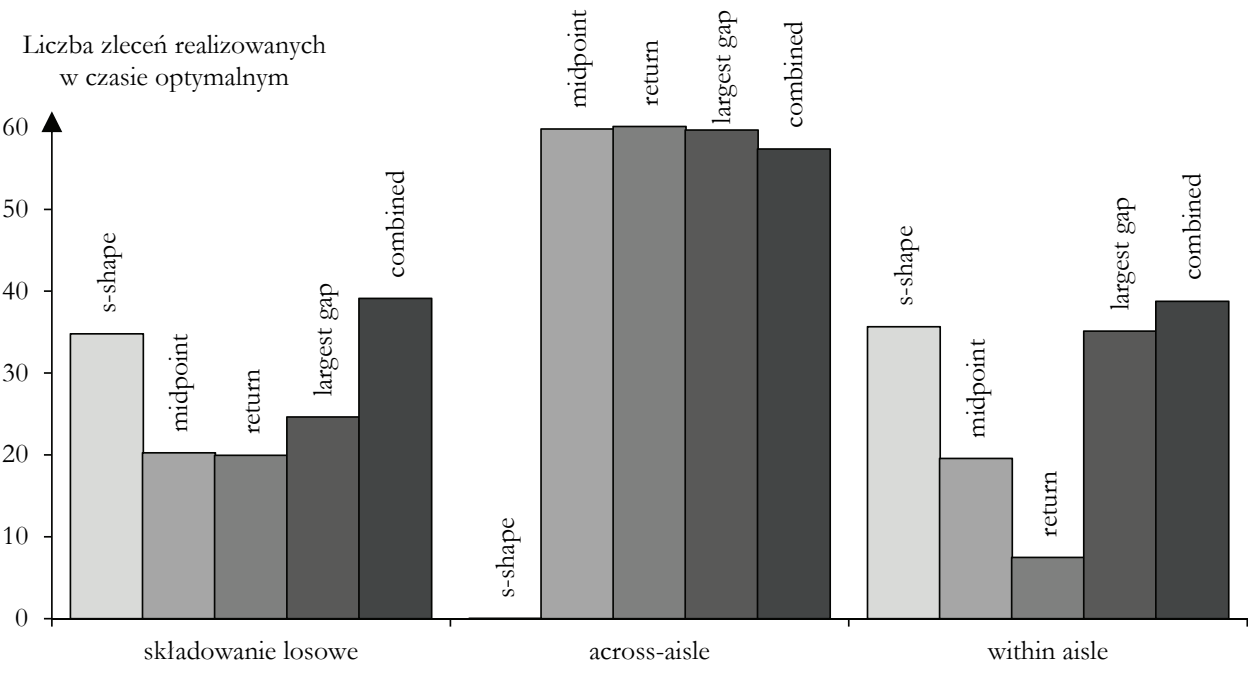

Metoda składowania towarów

Źródło: opracowanie własne.

Największe redukcje czasu kompletacji zamówień dla najpopularniejszych i najłatwiej implementowanych heurystyk: s-shape i return, w porównaniu z najlepszymi wariantami przy magazynie jednostrefowym, uzyskano przy kompletacji synchronicznej i podziale na 5 stref. Przy takiej organizacji pracy magazynu metoda s-shape w połączeniu ze składowaniem losowym albo zgodnym z polityką within-aisle dała podobne wartości średnich czasów kompletacji co metoda return z polityką across-aisle i były one lepsze od wariantu jednostrefowego o około $52 \%$ dla s-shape i blisko $44 \%$ dla return. Oczywiście, najbardziej byłoby korzystne wdrożenie metody wyznaczającej najkrótszą trasę lub chociaż heurystyki combined. Wykorzystanie w praktyce zarówno algorytmu Ratliffa i Rosenthala, jak i metody combined nie jest jednak proste i może powodować wiele innych niedogodności.

Drugim kryterium oceny kompletacji strefowej, obok średnich czasów kompletacji, jest współczynnik wykorzystania stref, który obrazuje przez jaki czas magazynierzy 
kompletują zamówienia (jako procent całkowitego czasu ich pracy). Pozostały czas to czas oczekiwania na zlecenie. Dla kompletacji sekwencyjnej problem nierównowagi wykorzystania stref w praktyce nie wystapił - minimalna wartość to ponad 97\% (tabela 2.). Założono, że bufory w strefach są nieograniczone, dlatego magazynierzy ze strefy pierwszej nie musieli czekać z rozpoczęciem kompletacji zlecenia, aż pracownicy z kolejnych stref zakończą poprzednie zlecenia. Stąd współczynnik wykorzystania pierwszej strefy wyniósł $100 \%$. Wysokie wartości w kolejnych strefach wynikają z tego, że przyjęto zbliżone rozkłady towarów szybko rotujących we wszystkich strefach.

RYSUNEK 9.

Odsetek zleceń, dla których trasa kompletacji odpowiadała trasie optymalnej przy kompletacji synchronicznej trzystrefowej, dla różnych heurystyk wyznaczania trasy i metod składowania towarów

Liczba zleceń realizowanych w czasie optymalnym
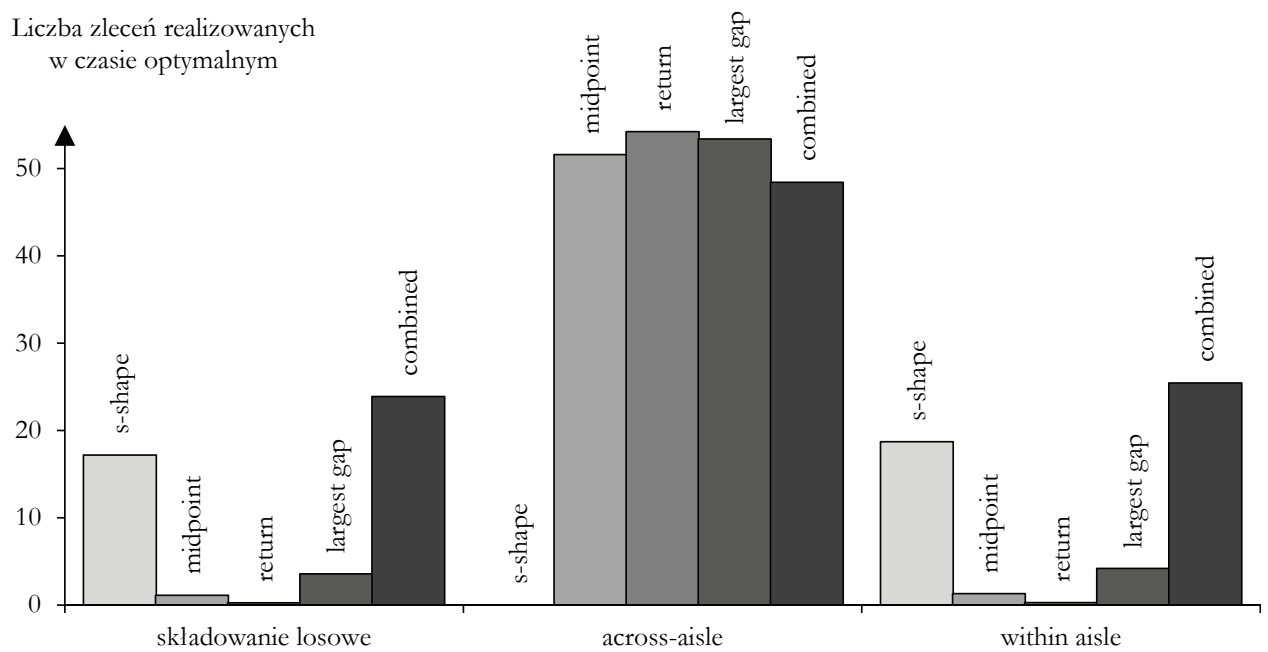

Metoda składowania towarów

Źródło: opracowanie własne.

Dla kompletacji synchronicznej, gdzie najpierw zamówienia dzielono na strefy, a następnie scalano, tworząc końcowe zlecenia, problem nierównowagi wykorzystania stref wystapił w większym stopniu (tabela 3.). Współczynniki wykorzystania stref wyniosły od $81 \%$ do $91 \%$, mimo że przyjęto założenie, iż średnia liczba towarów kompletowanych z każdej strefy jest zbliżona. Najgorzej sytuacja wyglądała przy podziale na 5 stref i heurystykach: s-shape, return i combined w połączeniu ze składowaniem losowym lub polityką within-aisle - aż 19\% czasu magazynierzy spędzali na oczekiwaniu na nowe zlecenie. Problem nierównowagi w najmniejszym stopniu miał miejsce dla 3 stref, metody s-shape i polityki across-aisle - tutaj było marnotrawione 9\% czasu pracy. Jane i Laih [2005, s. 489-496] podali przykład rzeczywistego magazynu, gdzie współczynniki wykorzystania stref nawet nie przekraczały 50\%, co było spowodowane znaczną różnicą w średnich liczbach towarów pobieranych w poszczególnych strefach. 
TABELA 2.

Współczynniki wykorzystania stref kompletacyjnych przy kompletacji sekwencyjnej

\begin{tabular}{|c|c|c|c|c|c|c|c|}
\hline \multirow{2}{*}{$\begin{array}{c}\text { Liczba } \\
\text { stref }\end{array}$} & \multirow{2}{*}{$\begin{array}{l}\text { Metoda } \\
\text { wyzna- } \\
\text { czania } \\
\text { trasy }\end{array}$} & \multirow{2}{*}{$\begin{array}{c}\text { Metoda } \\
\text { składowa- } \\
\text { nia } \\
\text { towarów }\end{array}$} & \multicolumn{5}{|c|}{ Współczynnik wykorzystania strefy (w \%) } \\
\hline & & & Strefa 1. & Strefa 2. & Strefa 3. & Strefa 4. & Strefa 5. \\
\hline 3 & s-shape & losowe & 100,00 & 97,22 & 99,97 & - & - \\
\hline 3 & midpoint & losowe & 100,00 & 97,59 & 99,97 & - & - \\
\hline 3 & return & losowe & 100,00 & 97,70 & 99,98 & - & - \\
\hline 3 & largest gap & losowe & 100,00 & 97,70 & 99,98 & - & - \\
\hline 3 & combined & losowe & 100,00 & 97,56 & 99,98 & - & - \\
\hline 3 & optimal & losowe & 100,00 & 97,72 & 99,98 & - & - \\
\hline 3 & s-shape & across-aisle & 100,00 & 99,67 & 99,78 & - & - \\
\hline 3 & midpoint & across-aisle & 100,00 & 99,50 & 99,84 & - & - \\
\hline 3 & return & across-aisle & 100,00 & 99,56 & 99,88 & - & - \\
\hline 3 & largest gap & across-aisle & 100,00 & 99,48 & 99,84 & - & - \\
\hline 3 & combined & across-aisle & 100,00 & 99,54 & 99,83 & - & - \\
\hline 3 & optimal & across-aisle & 100,00 & 99,56 & 99,84 & - & - \\
\hline 3 & s-shape & within-aisle & 100,00 & 99,45 & 99,73 & - & - \\
\hline 3 & midpoint & within-aisle & 100,00 & 98,73 & 99,55 & - & - \\
\hline 3 & return & within-aisle & 100,00 & 99,10 & 99,69 & - & - \\
\hline 3 & largest gap & within-aisle & 100,00 & 98,88 & 99,68 & - & - \\
\hline 3 & combined & within-aisle & 100,00 & 99,36 & 99,83 & - & - \\
\hline 3 & optimal & within-aisle & 100,00 & 99,29 & 99,85 & - & - \\
\hline 5 & s-shape & losowe & 100,00 & 99,98 & 97,31 & 99,70 & 99,51 \\
\hline 5 & midpoint & losowe & 100,00 & 99,97 & 97,05 & 99,58 & 99,40 \\
\hline 5 & return & losowe & 100,00 & 99,96 & 97,52 & 99,59 & 99,44 \\
\hline 5 & largest gap & losowe & 100,00 & 99,98 & 97,08 & 99,59 & 99,47 \\
\hline 5 & combined & losowe & 100,00 & 99,97 & 97,19 & 99,64 & 99,45 \\
\hline 5 & optimal & losowe & 100,00 & 99,98 & 97,46 & 99,72 & 99,39 \\
\hline 5 & s-shape & across-aisle & 100,00 & 99,18 & 99,20 & 98,48 & 98,18 \\
\hline 5 & midpoint & across-aisle & 100,00 & 99,80 & 99,08 & 98,88 & 98,52 \\
\hline 5 & return & across-aisle & 100,00 & 99,77 & 99,01 & 98,86 & 98,40 \\
\hline 5 & largest gap & across-aisle & 100,00 & 99,79 & 99,02 & 98,89 & 98,48 \\
\hline 5 & combined & across-aisle & 100,00 & 99,78 & 98,99 & 98,88 & 98,47 \\
\hline 5 & optimal & across-aisle & 100,00 & 99,77 & 98,99 & 98,87 & 98,44 \\
\hline 5 & s-shape & within-aisle & 100,00 & 99,81 & 99,01 & 99,02 & 98,85 \\
\hline 5 & midpoint & within-aisle & 100,00 & 99,73 & 98,85 & 99,01 & 98,55 \\
\hline 5 & return & within-aisle & 100,00 & 99,58 & 99,11 & 98,72 & 98,34 \\
\hline 5 & largest gap & within-aisle & 100,00 & 99,80 & 98,92 & 98,98 & 98,55 \\
\hline 5 & combined & within-aisle & 100,00 & 99,81 & 98,93 & 99,09 & 98,75 \\
\hline 5 & optimal & within-aisle & 100,00 & 99,80 & 99,02 & 99,03 & 98,64 \\
\hline
\end{tabular}

Źródło: opracowanie własne. 
TABELA 3.

Współczynniki wykorzystania stref kompletacyjnych przy kompletacji synchronicznej

\begin{tabular}{|c|c|c|c|c|c|c|c|}
\hline \multirow{2}{*}{$\begin{array}{c}\text { Liczba } \\
\text { stref }\end{array}$} & $\begin{array}{c}\text { Metoda } \\
\text { składowania } \\
\text { towarów }\end{array}$ & \multicolumn{7}{|c|}{$\begin{array}{c}\text { Średni współczynnik wykorzystania strefy (w \%) } \\
\text { dla metody wyznaczania trasy }\end{array}$} \\
\cline { 3 - 8 } & & s-shape & midpoint & return & $\begin{array}{c}\text { largest } \\
\text { gap }\end{array}$ & combined & optimal \\
\hline 3 & losowe & 85,19 & 88,19 & 85,02 & 88,20 & 85,86 & 87,43 \\
3 & across-aisle & 91,08 & 87,81 & 87,58 & 88,00 & 87,96 & 90,05 \\
3 & within-aisle & 85,13 & 88,06 & 85,33 & 88,03 & 85,74 & 87,36 \\
5 & losowe & 81,11 & 84,51 & 81,15 & 84,41 & 81,41 & 85,10 \\
5 & across-aisle & 87,21 & 82,31 & 82,12 & 82,70 & 83,34 & 86,41 \\
5 & within-aisle & 81,06 & 84,93 & 81,24 & 84,52 & 81,57 & 85,36 \\
\hline
\end{tabular}

Źródło: opracowanie własne.

\section{Podsumowanie}

Wdrożenie kompletacji strefowej w magazynie pozwala na redukcję średnich czasów kompletacji zamówień, ale tylko wtedy, gdy równocześnie zadba się o właściwe składowanie towarów szybko rotujących i dobór heurystyki wyznaczania trasy. Wydaje się, że te dwa ostatnie czynniki mają dużo większe znaczenie niż sam podział na strefy. Przeprowadzone eksperymenty świadczą o tym, że nieprawidłowo przeprowadzona kompletacja strefowa może nawet spowodować wydłużenie średnich czasów kompletacji zamówień. Heurystyki: midpoint, return, largest gap i combined powinny być stosowane w połączeniu z polityką składowania across-aisle, a heurystyka s-shape z polityką within-aisle. Wówczas nawet dla ponad 50\% zamówień trasa wygenerowana przez te heurystyki była optymalna.

Oprócz średnich czasów kompletacji, drugie kryterium stosowane przy ocenie kompletacji strefowej stanowiło wykorzystanie stref kompletacyjnych. W pracy założono, że rozkład towarów szybko rotujących we wszystkich strefach jest zbliżony do siebie. Mimo to można było zauważyć problem nierównowagi nakładu pracy w strefach przy kompletacji synchronicznej, gdzie dla określonych wariantów w niektórych strefach pracownicy nawet przez blisko $20 \%$ czasu pozostawali bezczynni, czekając na nowe zlecenie. Dla kompletacji sekwencyjnej problem ten wystapił w minimalnym stopniu. powinny być kontynuowane badania dotyczące stopnia wykorzystania stref. Interesujące byłoby określenie przybliżonego rozkładu czasu obciążenia stref, przyjmując, że rozkłady czasów kompletacji w strefach są znane, ale nie są zbliżone do siebie (jak założono w artykule). Inne problemy badane już przez naukowców, jednak wymagające, zdaniem autorów, dalszej analizy, to: ustalenie sposobu przydziału towarów do stref tak, aby równocześnie osiagnąć dwa cele, a mianowicie: minimalizację średniego czasu kompletacji i maksymalizację wykorzystania stref [Jane, Laih, 2005, s. 489-496], jak również tworzenie zleceń łączonych i ich harmonogramowanie w celu zapewnienia płynniejszej realizacji procesu kompletacji strefowej [Hong i in. 2012, s. 557-570]. 


\section{Wkład autorów w opracowanie artykułu}

dr Grzegorz Tarczyński - opracowanie koncepcji badań, współudział w przeprowadzeniu badań i opracowaniu wyników $-60 \%$

dr Michał Jakubiak - opracowanie koncepcji badań, współudział w przeprowadzeniu badań i opracowaniu wyników - 40\%

\section{Literatura}

de Koster R., 1994, Performance approximation of pick-to-belt orderpicking systems, "European Journal of Operational Research", no. 72(3), DOI 10.1016/0377-2217(94)90423-5.

de Koster R., Le-Duc T., Roodbergen K.J., 2007, Design and control of warehouse order picking: A literature review, "European Journal of Operational Research", no. 182(2), DOI 10.1016/j.ejor.2006.07.009.

Frazelle E.H., Apple J.M., 1994, Warehouse operations, [in:] The Distribution Management Handbook, J.A. Tompkins (ed.), McGraw-Hill, Nowy Jork.

Hong S., Johnson A., Peters B., 2012, Batch picking in narrow-aisle order picking systems with consideration for picker blocking, "European Journal of Operational Research", 221(3), DOI 10.1016/j.ejor.2012.03.045.

Jane C.C., Laih Y.W., 2005, A clustering algorithm for item assignment in a synchronized zone order picking system, "European Journal of Operational Research", no. 166(2), DOI 10.1016/j.ejor.2004.01.042.

Le-Duc T., de Koster R., 2005, Determining number of zones in a pick-and-pack orderpicking system, ERIM Report Series Reference No. ERS-2005-029-LIS, https://ssrn.com/ abstract $=800205$ (data wejścia: 19.11.2016).

Melacini M., Perotti S., Tumino A., 2011, Development of a framework for pick-and-pass order picking system design, "The International Journal of Advanced Manufacturing Technology", no. 53(9-12), DOI 10.1007/s00170-010-2881-2.

Ratliff H.D., Rosenthal A.S., 1983, Order-picking in a rectangular warehouse: a solvable case of the traveling salesman problem, "Operations Research", no. 31(3), DOI 10.1287/ opre.31.3.507.

Tarczyński G., 2012, Analysis of the impact of storage parameters and the size of orders on the choice of the method for routing order picking, "Operations Research and Decisions", no. 4(2012).

Tarczyński G., 2013, Warehouse Real-Time Simulator - How to Optimize Order Picking Time, Working Paper, http://ssrn.com/abstract=2354827 (data wejścia: 19.11.2016).

Van der Gaast J., de Koster R., Adan I., Resing J., 2012, Modeling and performance analysis of sequential zone picking systems, Working Paper, http://alexandria.tue.nl/repository/ books/751517.pdf (data wejścia: 19.11.2016).

Yu M., de Koster R., 2008, Performance approximation and design of pick-and-pass order picking systems, "IIE Transactions", no. 40(11), DOI 10.1080/07408170802167613.

Yu M., de Koster R., 2009, The impact of order batching and picking area zoning on order picking system performance, "European Journal of Operational Research", no. 198(2), DOI 10.1016/j.ejor.2008.09.011. 